\title{
Our experiences regarding combined use of pedicle plication and dermal flap suspension in inferior pedicle inverted-T scar reduction mammaplasty
}

\section{İnferior pedikülllü ters T skarlı redükssiyon mamaplastide pedikül plikasyonu ve dermal flep süspansiyonunun kombine kullanımına dair tecrübelerimiz}

Teoman Eskitaşçığlü ${ }^{1}$, Yalçın Yontar ${ }^{2}$

${ }^{1}$ Erciyes University Medical Faculty, Department of Plastic Reconstructive and Aesthetic Surgery, Kayseri, Turkey

${ }^{2}$ Acrbadem Kayseri Hospital, Department of Plastic Reconstructive and Aesthetic Surgery, Kayseri, Turkey

Corresponding author: Yalçın Yontar, MD, Acıbadem Kayseri Hospital, Department of Plastic Reconstructive and Aesthetic Surgery, Kayseri, Turkey E-mail: dr.yyontar@gmail.com

Received/Accepted: May 18, 2019 /September 28, 2019

Conflict of interest: There is not a conflict of interest.

\section{SUMMARY}

Objective: To present clinical outcomes and experiences regarding the combined use of plication and dermal flap suspension of inferior pedicle in inverted-T scar reduction mammaplasty.

Method: One hundred and twenty-one cases with bilateral macromastia were operated by using the present technique between March 2008 and November 2017. The cases were reviewed retrospectively regarding demographics, preoperative findings, and postoperative outcomes. Of the 121 cases, 22 were excluded from the study analysis.

Results: The mean age of the cases was 39.77 years. The mean preoperative diameter of NAC and the mean preoperative distances of mid-clavicle-tonipple, nipple-to-IMF and IMF were 6.54, 33.48, 15.98 and $25.09 \mathrm{~cm}$, respectively. The mean weight of excised tissue per case was $2033.32 \mathrm{~g}$. There were three cases with unilateral T-junction dehiscence and two cases with unilateral T-junction necrosis. Furthermore, one case presented with bilateral, and two cases presented with unilateral superficial partial necrosis of NAC. At long-term, six cases had a slight asymmetry, two had bilateral pseudoptosis, and three had bilateral hypertrophic scarring among the transverse incision of the inverted-T scar. One case underwent bilateral excision of lateral dog ears, and one underwent surgery due to unilateral fat necrosis at postoperative $3^{\text {rd }}$ month - two cases presented with unilateral loss of NAC sensation. The overall satisfaction with the operation was high. Conclusions: The outcomes of this study led us to conclude that the combined use of pedicle plication and dermal flap suspension improves the shape and position controllability of the inferior pedicle, produces a projectile and stabilized breast mound, aids in achieving satisfactory longterm cosmetic outcomes, and prevents breast deformities. Extended operative time can be considered as a disadvantage of the technique.

Keywords: Breast reduction, dermal flap, inferior pedicle, mammaplasty, pedicle plication
Teoman Eskitaşçıŏlu

Yalçın Yontar

ORCID IDs of the authors: T.E. 0000-0001-9298-5078 Y.Y. 0000-0002-2598-3248 
Amaç: Bu çalışmada, inferior pediküllü ters T skarlı redüksiyon mamaplasti uygulanan hastalarda pedikül plikasyonu ve dermal flep süspansiyonunun kombine kullanımıyla ilgili klinik sonuçların ve tecrübelerin aktarılması amaçlanmiştır.

Yöntem: Mart 2008 ve Kasım 2017 tarihleri arasında bilateral makromasti nedeniyle 121 hastaya tariflenen teknikle redüksiyon mamaplasti uygulandi. Demografik veriler, preoperatif bulgular ve postoperatif sonuçlar açısından olgular retrospektif olarak değerlendirildi. Yirmi iki hasta çalışmaya dahil edilmedi.

Bulgular: Hastaların ortalama yaşı 39,77'ydi. Meme başı-areola kompleksinin preoperatif ortalama çapı ve klavikula orta noktası-meme başı, meme başı-inframamarian kıvrım ve inframamarian kıvrımın preoperatif ortalama uzunluğu, sırasıyla, 6,54, 33,48, 15,98 ve 25,09 cm'ydi. Hasta bașına eksize edilen meme dokusu ortalama ağırlığı 2033,32 g'dı. Ters T skarın birleşim noktasında üç hastada unilateral detaşman, iki hastada ise unilateral nekroz gözlendi. Ayrıca bir hastada bilateral, iki hastada ise unilateral olarak meme başı-areola kompleksinde kısmi yüzeyel nekroz gözlendi. Uzun dönemde altı hastada hafif düzeyde asimetri, iki hastada bilateral psödopitozis ve üç hastada ters $\mathrm{T}$ skarın transvers insizyonunda bilateral hipertrofik skar gelișimi gözlendi. Bir hastada bilateral köpek kulağı deformitesinin düzeltilmesi, bir hastada ise unilateral yağ nekrozunun eksizyonu amaciyla postoperatif 3 . ayda cerrahi işlem gerçekleştirildi. İki hastada unilateral meme başı-areola kompleksinde duyu kaybı gözlendi. Operasyon sonrası hasta memnuniyeti yüksekti.

Sonuç: Bu çalışmanın sonuçları pedikül plikasyonu ve dermal flep süspansiyonunun kombine kullanımıyla inferior pedikülün istenilen pozisyonda konumlandırılarak şekillendirilebildiğini, projektil ve stabil bir meme kitlesinin elde edildiğini ve meme deformitelerinin önüne geçilerek uzun dönemde tatminkar kozmetik sonuçların elde edildiğini göstermektedir. Uzamış cerrahi süre tekniğin bir dezavantajı olarak görülebilir.

Anahtar sözcükler: Dermal flep, inferior pedikül, meme küçültme, pedikül plikasyonu, redüksiyon mamaplasti

\section{INTRODUCTION}

Macromastia or breast hypertrophy is defined as an excessive and generalized enlargement of one or both breasts above the average proportion with no pathologic processes, lesions, or underlying diseases. ${ }^{1,2}$ The recommended treatment approach for symptomatic cases of macromastia is by reduction mammaplasty. Combination of various skin excision patterns, including periareolar, J-shaped, L-shaped, horizontal, vertical, or inverted-T pattern and different dermoglandular flap designs, including superior, superomedial, lateral, inferior, central, or vertical bipedicle, can be employed depending on size of the breast, degree of ptosis, and preference and experience of the surgeon. ${ }^{3,4}$

The vertical or inverted-T skin excision patterns are the most commonly preferred techniques for reduction mammaplasty. ${ }^{5-7}$ The superior or superomedial pedicle is generally used in the vertical scar pattern, while many surgeons favor an inferior pedicle in the inverted-T pattern. The inferior pedicle is very reliable in maintaining breastfeeding ability and retaining sensation and vascularity of the nipple-areola complex (NAC), it can eliminate the need for NAC grafting even in cases of gigantomastia, and it has a smooth learning curve for junior trainees. $^{4,8-11}$ However, development of pseudoptosis (bottoming-out deformity) due to gravity-induced stretching of vertical limb of the inverted-T scar and a flat and boxy-shaped breast with poor projection are highlighted as its major criticisms. ${ }^{10,12-16}$ Furthermore, timeconsuming deepithelialization of a large area and tension at the T-junction, which may result in difficulty in suture closure and subsequent wound dehiscence, are noted as its technical challenges. ${ }^{10,16}$

In this article, it was aimed to present clinical outcomes and experiences in a series of inverted- $T$ scar reduction mammaplasty, in which plication and dermal flap suspension of the inferior pedicle were performed together. While combined use of these maneuvers helps to avoid unintended outcomes of the inferior pedicle, it aids in generating a projectile and conical breast mold with satisfying cosmetic results.

\section{MATERIAL AND METHODS}

From March 2008 to November 2017, 121 cases with bilateral macromastia were operated by the authors with the present technique in two different institutions. Of the cases, 22 were excluded from the analysis due to the use of free nipple grafts, having a follow-up period of fewer than 12 months, or missing data records regarding demographics and breast measurements. Preoperative physical examination and breast ultrasonography were performed for all cases. For the cases with an age of more than 40 years, mammography was 
performed in addition to ultrasonography. Further investigations were carried out only when abnormal or suspicious radiological findings were detected.

Written informed consent of all cases, and the institutional ethics committee approval was obtained (ATADEK; 2019-14/68), and the study was performed in accordance with the principles of the Declaration of Helsinki.

\section{Preoperative markings}

Standard photographs of frontal, lateral, and oblique views were taken of all cases before the breast marking performed in an upright standing position. The new nipple was placed on the breast meridian at the anterior projection of IMF or at the level of mid humerus on cases with ptosis of IMF. A modified Wise pattern technique, as already described by Özyazgan et al. ${ }^{17}$ was performed, and a NAC was marked with a diameter of $42-45 \mathrm{~mm}$. An $8-10 \mathrm{~cm}$ wide inferior pedicle was located over the breast meridian, and it was marked out as a curve around the NAC leaving a $1-3 \mathrm{~cm}$ margin. The equilateral triangular dermal flaps were marked on either side of the inferior pedicle with a base located between its superior pole and $6-7 \mathrm{~cm}$ below to the inferior pole of the NAC.

\section{Surgical technique (Figure 1)}
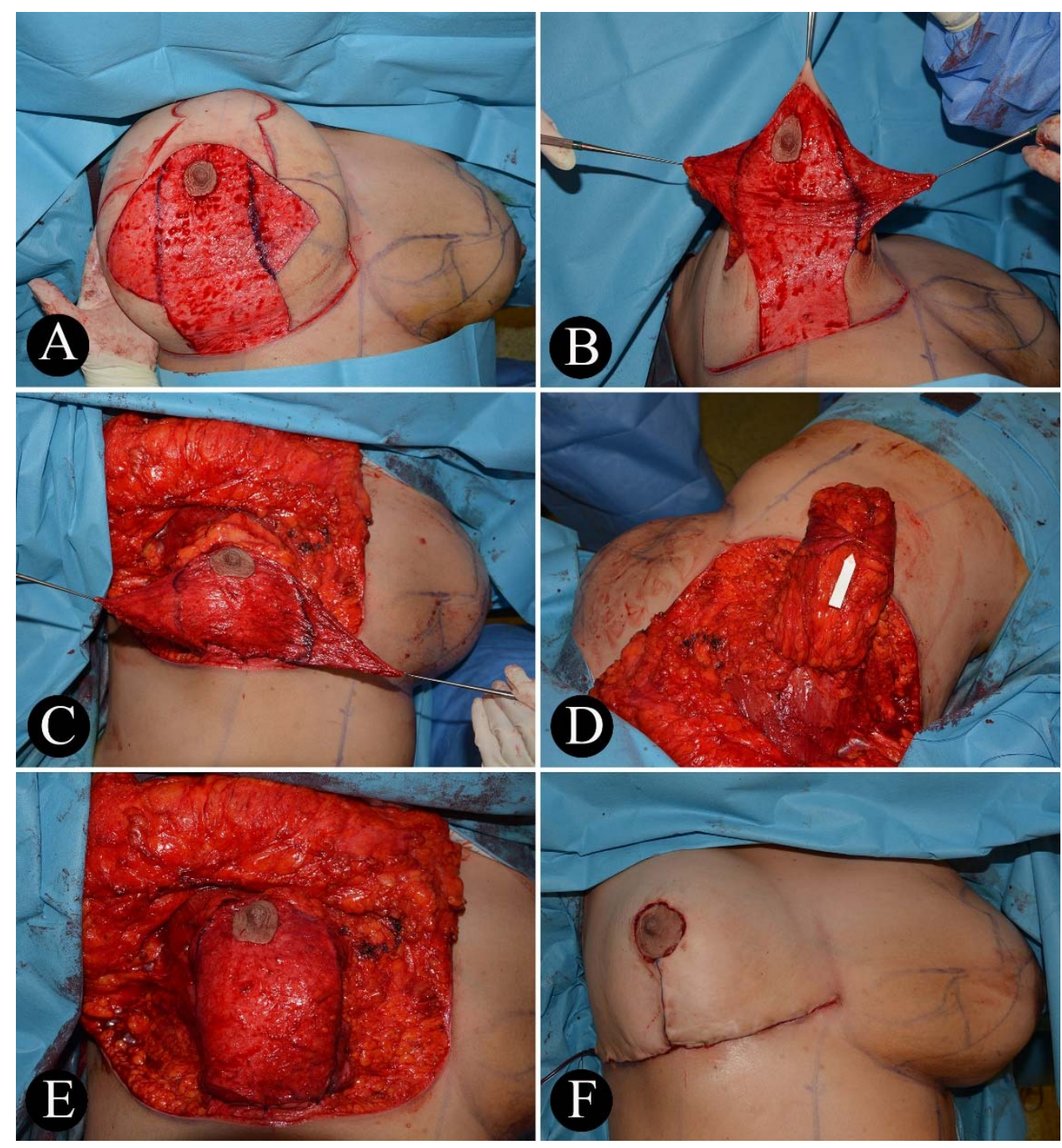

Figure 1: A. Deepithelialized triangular dermal flaps and inferior pedicle, B. elevated triangular dermal flaps with a thickness of 1-1,5 cm, C. plicated inferior pedicle, D. sutured tips of the medial and lateral triangular dermal flaps at the posterior aspect of the inferior pedicle, which was shown with an arrow, E. final appearance of the inferior pedicle fixed to the pectoralis fascia, and F. subcutaneous suture closure of the right breast. 
All surgical procedures were performed under general anesthesia with prophylactic antibiotic usage and strict sterile precautions. After infiltration of the breast parenchyma with a tumescent solution, including lactated Ringer's solution, lidocaine, and epinephrine, dermal incisions were performed according to the preoperative markings. Tumescent infiltration was not performed at the base of the inferior pedicle to avoid circulatory impairment. A breast tourniquet was then applied, and without intradermal tumescent infiltration, triangularshaped dermal flaps and inferior pedicle were de-epithelialized, except for the NAC. Subsequently, the triangular dermal flaps were elevated with a thickness of $1-1.5 \mathrm{~cm}$ to avoid injury to the subdermal plexus. The inferior pedicle was then raised with great care to preserve the horizontal septum, excess skin and dermo-glandular tissue among the Wise pattern were excised leaving a breast tissue with a thickness of $1.5-2 \mathrm{~cm}$ on the chest wall to protect the intercostal nerves sensing the NAC, and the skin flaps were thinned until the desired breast volume was achieved.

Pedicle plication was performed horizontally with running polydioxanone sutures. The superior plication border was located $6-7 \mathrm{~cm}$ below the inferior pole of the NAC, where the dermal flaps end inferiorly, and the inferior plication border was located $1 \mathrm{~cm}$ above the IMF. On the inferior border, a superficial incision exposing the subcutis was performed to facilitate the plication. Subsequently, the tips of the medial and lateral triangular dermal flaps were sutured together at the posterior aspect of the inferior pedicle and then to the pectoralis fascia with deep muscle bites at the level of the third or fourth rib using a 2-0 polydioxanone suture. The superior pole of the inferior pedicle was then sutured to the pectoralis fascia at the level of the second or third rib to provide a stable pedicle fixation. After meticulous hemostasis and insertion of the closed-suction drains through stab skin incisions on each breast, temporary skin sutures were placed, and the patient was placed in a semi-sitting position to check the symmetry of the breasts. The skin incisions were closed by interrupted and running dermal sutures. The dressing was done with dry gauze layers, and compressing adhesive tapes were applied to support and shape the breasts. All excised breast tissue was weighed and submitted for histopathologic examination.

\section{Postoperative care}

Starting from the postoperative day 1 , a wireless surgical bra was fitted, and the patient was advised to wear the bra for at least 4-6 weeks. The drains were removed when the drainage was less than $20 \mathrm{ml}$ during 24 hours, and the cases were generally discharged after the drains were removed.

\section{RESULTS}

The mean age and follow-up period of the cases were $39.77 \pm 12.05$ years (range, 17 to 67 years) and $28.19 \pm 11.60$ months (range, 12 to 61 months), respectively. Hypertension was the most common accompanying disease $(n=9)$, followed by asthma $(n=5)$, hypothyroidism $(n=$ $4)$, diabetes mellitus $(n=3)$, and rheumatoid arthritis $(n=1)$. With respect to preoperative measurements, the mean distances of midclavicle-to-nipple, nipple-to-IMF, and IMF and diameter of NAC were $33.48 \pm 4.89 \mathrm{~cm}, 15.98$ $\pm 3.92 \mathrm{~cm}, 25.09 \pm 4.13 \mathrm{~cm}$, and $6.54 \pm 1.55 \mathrm{~cm}$, respectively. The mean weight of excised tissue per case was $2033.32 \pm 928.42$ g. No premalignant or malignant pathologic findings were noted on the histopathological examination of the excised tissue specimens. The mean preoperative breast measurement values of right and left breasts are presented in Table 1.

Table 1: Mean preoperative measurements of right and left breasts.

\begin{tabular}{|l|c|c|}
\hline Measurements & Right breast (mean \pm SD) & Left breast (mean \pm SD) \\
\hline Midclavicle-nipple (cm) & $33.58 \pm 4.89$ & $33.39 \pm 4.93$ \\
\hline Nipple-IMF (cm) & $15.98 \pm 3.94$ & $15.97 \pm 3.92$ \\
\hline IMF (cm) & $25.05 \pm 4.08$ & $25.13 \pm 4.20$ \\
\hline NAC (cm) & $6.56 \pm 1.55$ & $6.52 \pm 1.56$ \\
\hline Weight of excised tissue (g) & $1021.32 \pm 487.79$ & $1010.84 \pm 461.19$ \\
\hline
\end{tabular}


There were three cases with unilateral $\mathrm{T}$ junction dehiscence and two cases with unilateral T-junction necrosis due to excessive tension during skin closure. Furthermore, one case presented with bilateral, and two cases presented with unilateral superficial partial necrosis of the NAC in the form of epidermolysis. All wounds healed spontaneously with dressing changes, required no further surgical intervention, and did not impair the final appearance of the breasts. At long-term, six cases had a slight asymmetry, and two had bilateral pseudoptosis, but all were satisfied and did not request a further surgical correction. Three cases showed bilateral extensive hypertrophic scarring among the transverse incision of the inverted- $\mathrm{T}$ scar, and all demonstrated considerable improvement following intralesional corticosteroid injections. One case underwent bilateral excision of the dog ears at the lateral end of the transverse scars, and one underwent surgery due to unilateral fat necrosis of the lower pole at postoperative $3^{\text {rd }}$ month. Two cases presented with unilateral loss of NAC sensation. The overall satisfaction with the operation was high. Three representative cases are shown in Figures $2-4$.

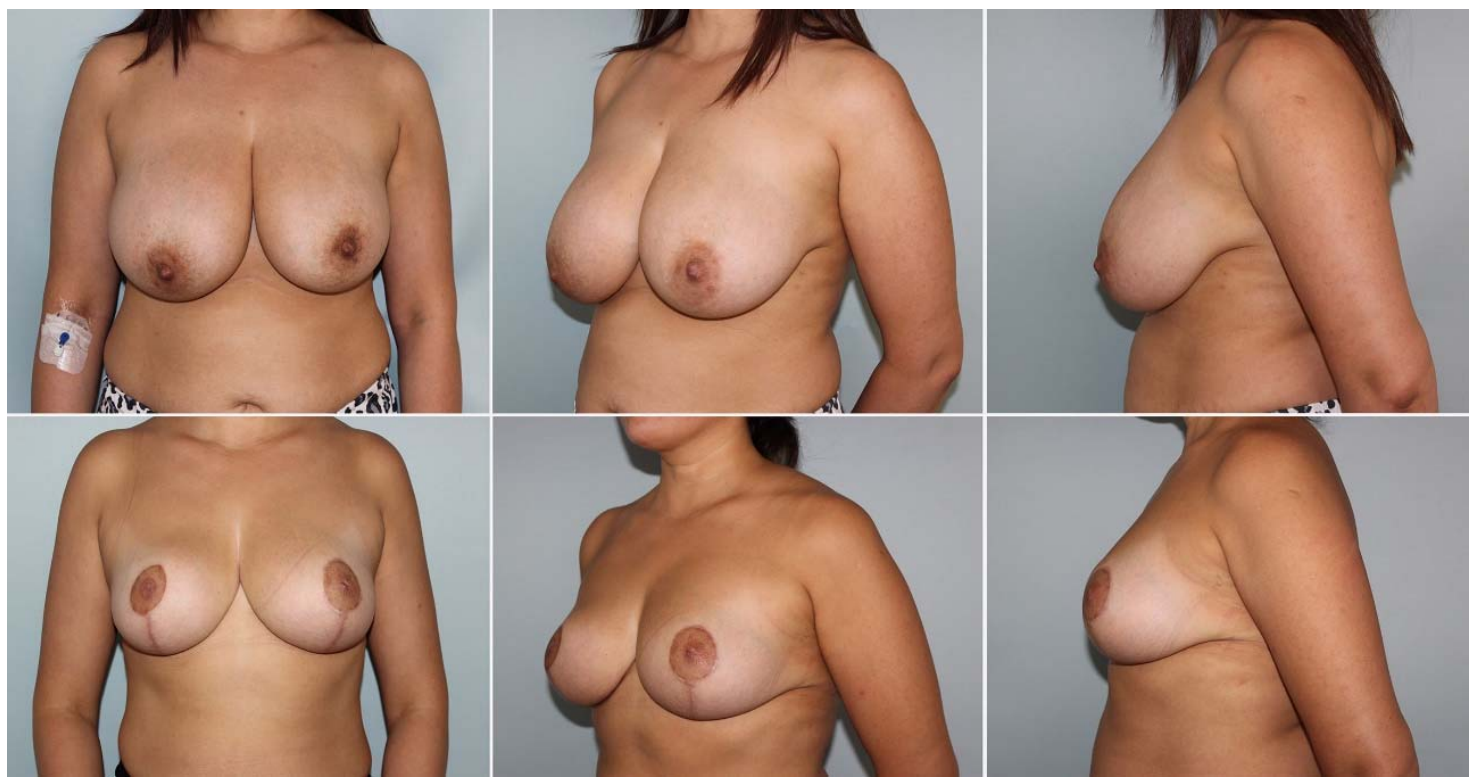

Figure 2: Before (upper row) and $12^{\text {th }}$ month (lower row) views of a 40 -year-old case after resection of $550 \mathrm{~g}$ from the right breast and $470 \mathrm{~g}$ from the left breast.

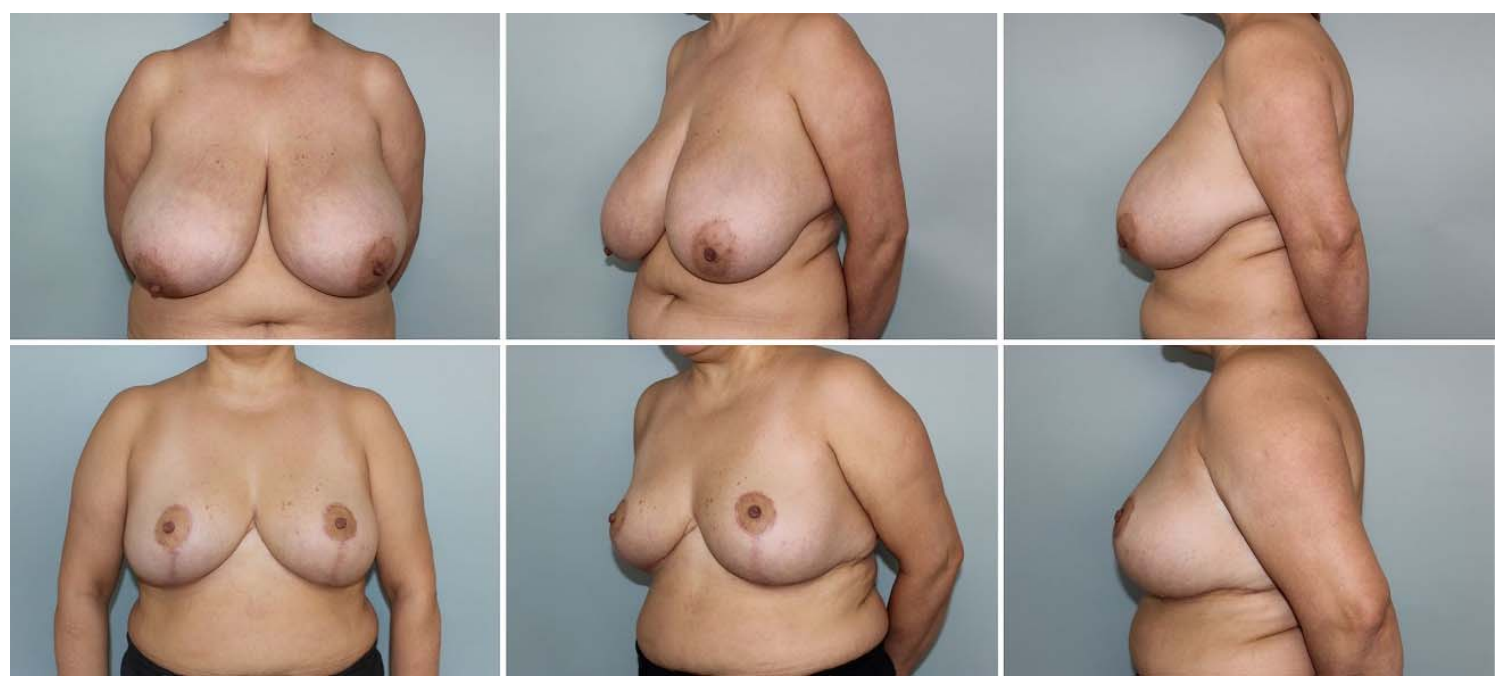

Figure 3: Before (upper row) and $15^{\text {th }}$ month (lower row) views of a 47 -year-old case after resection of $740 \mathrm{~g}$ from the right breast and $840 \mathrm{~g}$ from the left breast. 


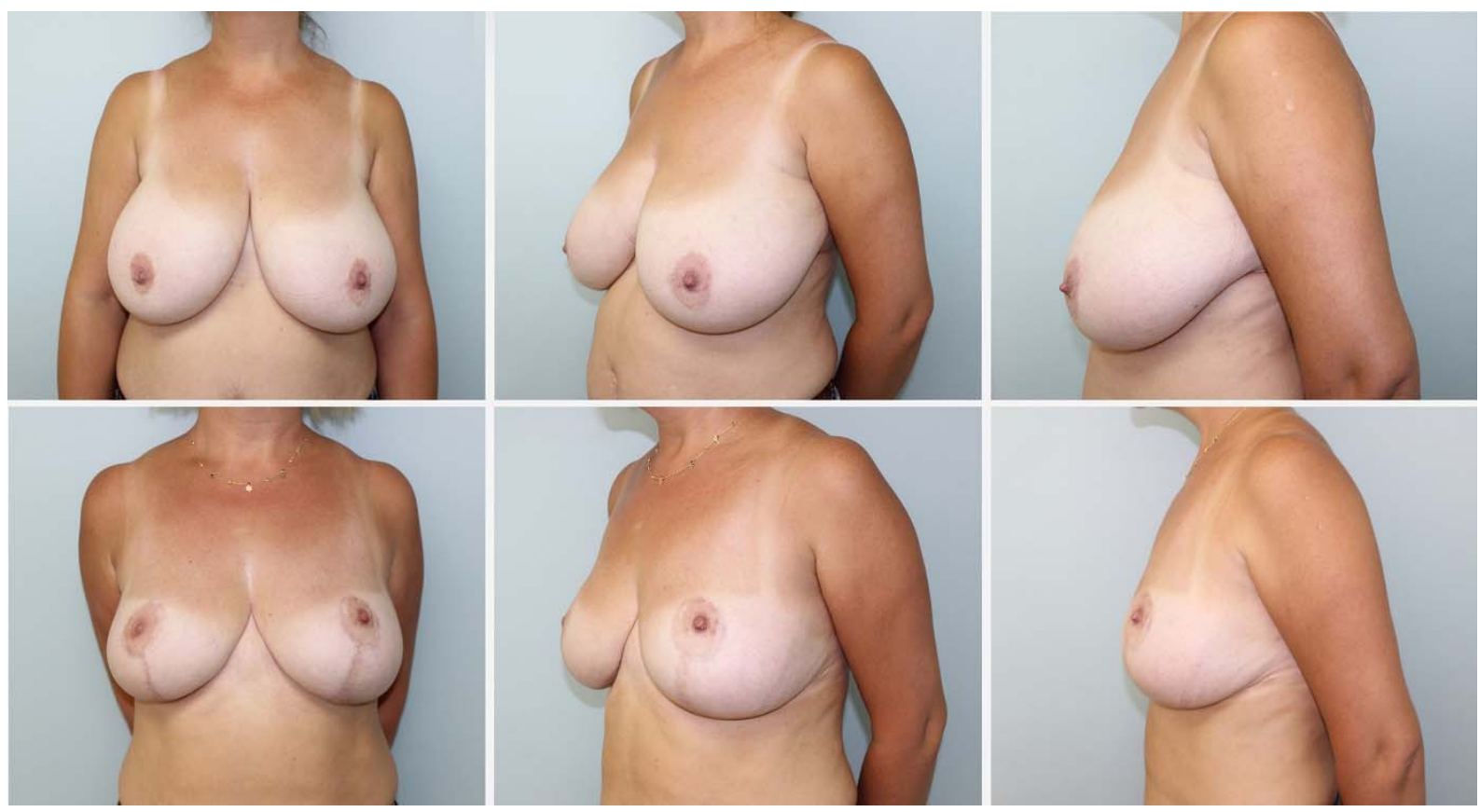

Figure 4: Before (upper row) and $30^{\text {th }}$ month (lower row) views of a 45 -year-old case after resection of $810 \mathrm{~g}$ from the right breast and $830 \mathrm{~g}$ from the left breast.

\section{DISCUSSION}

Suspension of the inferior pedicle by using pectoralis major muscle flap, ${ }^{18}$ superficial fascial system, ${ }^{19}$ autologous dermal flaps, ${ }^{10,12,20-}$ 22 acellular dermal matrix, ${ }^{23,}$ etc., have been introduced to overcome unintended outcomes of the inferior pedicle. With many specific modifications defined, autologous dermal flaps are the procedure of choice today by most plastic surgeons. ${ }^{12}$ Various advantages of the dermal flaps over other suspension techniques, including ease of flap dissection and shaping, lack of donor site morbidity, cost-effectiveness, and benefits of using an autologous and biological material, can be considered as the primary reasons for their popularity. ${ }^{12,24}$

In the literature, there are various published series investigating the effectiveness of the dermal flaps with or without plication of the inferior pedicle. In a study performed by Kankaya et al., ${ }^{22}$ clinical outcomes of a dermal flap suspension technique were analyzed retrospectively in thirteen cases followed-up more than one year. In the surgical procedure, two pairs of quadrangular-shaped dermal flaps were elevated from each side of the inferior pedicle and without its plication, the pedicle was fixed to the rib periosteum through the dermal flaps. The authors stated that the technique they used eliminates the requirement for the pedicle plication in terms of preventing pseudoptosis. In another study performed by Temel et al., ${ }^{20}$ a similar modification, in which two pairs of quadrangular- and triangularshaped dermal flaps were used to suspend the pedicle to the rib periosteum, was performed in a more extensive series. The authors reported that there were no cases with the development of pseudoptosis and breast asymmetry, and most cases were satisfied with the postoperative appearance of the breasts. The reason stated for not to perform the pedicle plication was the concerns of the authors regarding the circulatory compromise of the NAC. In our opinion, both techniques can be useful for the prevention of pseudoptosis and recurrent ptosis, if the appropriate suspension of the inferior pedicle is performed by using the defined dermal flap modifications. However, the boxy breast appearance may be a significant problem in long-term due to anterior compression of the pedicle, which may be observed due to its fixation to the side pectoralis fascia under high tension by the dermal flaps and also due to not using pedicle plication.

The pedicle plication is a critical maneuver in inferior pedicle inverted- $T$ scar reduction mammaplasty for several advantages, most importantly, it reduces tension at the T-junction by lifting the IMF and decreases the risk of wound dehiscence and skin necrosis, which was observed only in five cases of the present series. Furthermore, by folding the pedicle on itself 
and shortening the pedicle length, it aids in increasing projection of the pedicle, placing the $\mathrm{NAC}$ in the desired position, and producing a cone-shaped pedicle mound with the NAC centered on it. Its ability to minimize the stretching of the vertical limb of the inverted-T scar, which is widely recognized as the leading cause of pseudoptosis, can be regarded as another advantage of the pedicle plication. ${ }^{9,10,12,25}$ Although there is a concern that the plication can lead to arterial insufficiency and venous congestion of the NAC due to the increase of tension over the vascular structures of the pedicle, ${ }^{20}$ it is our observation and others that this maneuver can be used reliably, even with the dermal flap suspension techniques. ${ }^{10,12}$ Despite the loss of continuity of dermal and subdermal plexuses due to a dermal incision performed to facilitate the plication, only three cases of the present series presented with unilateral $(n=2)$ or bilateral $(n=1)$ superficial partial necrosis of the NAC. In our opinion, it was primarily due to the relatively longer nipple-IMF distance of these cases than the total sample, with a mean of $21.33 \mathrm{~cm}$. It should also be noted that, in a study performed by Iwuagwu and Drew, ${ }^{26}$ deskinning of the inferior pedicle, a more aggressive maneuver than performing a dermal incision, was shown not to increase the risk of circulatory complications of NAC in reduction mammaplasty.

The fact that the plication does not address medial and lateral portions of the inferior pedicle, ${ }^{10}$ this maneuver may not be able to prevent lateral bulging and boxy breast appearance alone. To solve this issue, the plication was combined with dermal flap suspension in the present series, and the tips of dermal flaps were sutured to each other at the posterior aspect of the inferior pedicle. This maneuver caged and compressed the plicated pedicle on both sides and thus it provided a narrow breast mound and an increase at the projection of pedicle. In our opinion, the low rates of postoperative breast deformities and circulatory complications of NAC of this series demonstrate success and reliability of combining pedicle plication with dermal flap suspension.

To the best of our knowledge, there are two published series in the literature in which dermal flap suspension is combined with inferior pedicle plication during reduction mammaplasty. ${ }^{10,12}$ In a study performed by Echo et al., ${ }^{12}$ the technique was performed in 66 cases presented with macromastia. The authors reported that satisfactory and favorable longterm outcomes were obtained, and postoperative breast deformities and circulatory complications of NAC were not observed in any of the cases. In the other study performed by Zic et al., ${ }^{10}$ more laterally extending triangular dermal flaps were used to suspend the pedicle, and the authors called the technique "dermal cage." Of the 26 cases they submitted to surgery, one developed pseudoptosis, two presented with necrosis of NAC, and eight had a slight asymmetry. The authors stated that most of the cases with breast asymmetry were early in their series, and this outcome was mainly attributed to the authors' learning curve. In both clinical series, the dermal flaps were designed as a triangle on each side of the inferior pedicle, as in the technique described by Aydin et al. ${ }^{27}$ and as we performed. Based on our clinical experience and as defined by the authors, easy manipulation of triangular-shaped dermal flaps during the suspension of the inferior pedicle is the main reason to prefer this flap pattern.

As limitations of the present study, lack of postoperative breast measurements, lack of a quantitative method regarding the diagnosis of pseudoptosis, and also lack of a scale to measure patients' postoperative satisfaction did not prevent us from being able to conclude our findings in such a large series. We believe that a further longitudinal and prospective study may help to confirm the results of the present study.

\section{CONCLUSION}

The outcomes of the present study suggest that combining the pedicle plication with the dermal flap suspension improves the shape and position controllability of the inferior pedicle and thus contributes to producing a projectile and stabilized breast mound. It is an effective means of achieving satisfactory long-term outcomes and preventing postoperative deformities in cases undergoing inferior pedicle inverted-T scar reduction mammaplasty. Extended operative time due to a larger area of de-epithelialization than the routine procedure and applying more than one technical maneuver can be considered as a disadvantage of the present technique. However, these can be overcome easily by subsequent surgical experience. 
Supporting information: This study was accepted to be presented as an oral presentation at the $41^{\text {st }}$ National Congress of Turkish Society of Plastic Reconstructive and Aesthetic Surgeons, in Samsun, Turkey, October $26^{\text {th }}$ to $30^{\text {th }}$.

\section{REFERENCES}

1. Rahman GA, Adigun IA, Yusuf IF. Macromastia: a review of presentation and management. Niger Postgrad Med J 2010; 17: 45-9.

2. Pérez-Panzano E, Güemes-Sánchez A, Gascón-Catalán A. Quality of Life Following Symptomatic Macromastia Surgery: Short-and Long-term Evaluation. Breast J 2016; 22: 397406.

3. Rogliani M, Gentile P, Labardi L, Donfrancesco A, Cervelli V. Improvement of physical and psychological symptoms after breast reduction. J Plast Reconstr Aesthet Surg 2009; 62: 1647-9.

4. Wong $\mathrm{C}$, Vucovich $\mathrm{M}$, Rohrich R. Mastopexy and reduction mammoplasty pedicles and skin resection patterns. Plast Reconstr Surg Glob Open 2014; 2: e202.

5. Moschella F, Cordova A, Toia F. Gigantomastia. In: Scuderi N, Toth B (eds). International Textbook of Aesthetic Surgery, first edn. Berlin: Springer, 2016; 239-45.

6. Makboul M, Abdelhamid MS, Al-Attar GS. Long-term follow-up and patient satisfaction after reduction mammoplasty: Superomedial versus inferior pedicle. Indian J Plast Surg 2016; 49: 214-9.

7. Sezgin B, Fındıkçıŏlu K, Sibar S, Barut İ, Ayhan $\mathrm{S}$, et al. Geçmişten günümüze klinikte meme küçültme: geriye dönük kesitsel bir bakış. Turk J Plast Surg 2012; 20: 19-22.

8. Lacerna M, Spears J, Mitra A, Medina C, McCampbell E, et al. Avoiding free nipple grafts during reduction mammaplasty in patients with gigantomastia. Ann Plast Surg 2005; 55: 21-4.

9. Pennington DG. Improving the results of inferior pedicle breast reduction using pedicle suspension and plication. Aesthetic Plast Surg 2006; 30: 390-4.

10. Zic R, Vlajcic Z, Dewing D, Zambelli M, Stanec Z. The "dermal cage": a modification of the inferior pedicle breast reduction. Aesthetic Plast Surg 2013; 37: 364-71.
11. Cruz NI, Korchin L. Lactational performance after breast reduction with different pedicles. Plast Reconstr Surg 2007; 120: 35-40.

12. Echo A, Guerra G, Yuksel E. The dermal suspension sling: shaping the inferior pedicle during breast reduction. Aesthetic Plast Surg 2011; 35: 608-16.

13. Brown RH, Izaddoost S, Bullocks JM. Preventing the "bottoming out" and "stargazing" phenomena in inferior pedicle breast reduction with an acellular dermal matrix internal brassiere. Aesthetic Plast Surg 2010; 34: 760-7.

14. Romano JJ, Francel TJ, Hoopes JE. Free nipple graft reduction mammoplasty. Ann Plast Surg 1992; 28: 271-6.

15. Hansen JE. Avoiding the unfavorable outcome with wise pattern breast reduction. Clin Plast Surg 2016; 43: 349-58.

16. Waltho DA, Kaur M, Farrokhyar F, Banfield LE, Thoma A. Inverted $T$ versus vertical scar incision technique for women undergoing breast reduction surgery. Cochrane Database Syst Rev 2016, Issue 2. Art. No.: CD012094.

DOI: 10.1002/14651858.CD012094.

17. Özyazgan İ, Eskitaşçığlu T, Baykan H, Günay GK. İnferior Piramidal Pediküllü Glandüler Flep İle Meme Küçültme Ameliyatında "Anahtar Deliği" Kalıbının Kullanımına Yeni Bir Yaklaşım. Turk J Plast Surg 2005; 13: 84-8.

18. Sumpter K, Gershenbaum S, Cartwright MJ. Bifurcated Inferior Pedicle with a BucketHandle Pectoralis Flap to Enhance Superior Pole Fullness in Breast-Reduction Surgery. Am J Cosm Surg 2003; 20: 35-8.

19. Lockwood T. Reduction mammaplasty and mastopexy with superficial fascial system suspension. Plast Reconstr Surg 1999; 103: 1411-20.

20. Temel M, Karakaş AO, Dokuyucu R, Türkmen A. "The dermal internal brassiere flap," a new modification of inferior pedicle breast reduction technic. Aesthetic Plast Surg 2015; 39: 350-8.

21. Hinderer UT. Mammaplasty: The dermal brassière technique. Aesthetic Plast Surg 1978; 2: $1-20$. 
22. Kankaya Y, Oruç M, Sungur N, Gürsoy K, Özer K, et al. Four flap suspension technique for prevention of bottoming out after breast reduction. Ann Surg Treat Res 2016; 90:10-5.

23. Brown RH, Izaddoost $\mathrm{S}$, Bullocks JM. Preventing the "bottoming out" and stargazing" phenomena in inferior pedicle breast reduction with an acellular dermal matrix internal brassiere. Aesthetic Plast Surg 2010; 34: 760-7.

24. Mutlu OO, Colak O, Atay M. Abdominal Wall Hernias and Their Repair with Inverse Abdominoplasty. In: Tiryaki $\mathrm{T}$ (ed). Inverse Abdominoplasty, first edn. Berlin: Springer, 2017; 157-73.
25. Simsek T, Engin MS, Abdullayev A, Kucuker I, Demir A, et al. Accordion-style pedicle suspension in inferocentral pedicled mammoplasty. J Plast Surg Hand Surg 2016; 50: 307-14.

26. Iwuagwu OC, Drew PJ. Deskinning versus deepithelialization for inferior pedicle reduction mammoplasty: a prospective comparative analysis. Aesthetic Plast Surg 2005; 29: 202-4.

27. Aydin H, Uluğ BT AÇ. Reduction Mammaplasty Using Inferior Pedicle Technique Combined with Dermal Suspension. In: Shiffman MA (ed). Mastopexy and Breast Reduction, first edn. Berlin: Springer, 2009; 429-33. 